$\xi=1$

\title{
Phytochemical composition, in vitro antioxidant activity and acute toxicity of Irvingia gabonensis (O'Rorke) baill ethanolic leaf extract
}

\author{
Efosa Godwin Ewere ${ }^{1 *}$, Emmanuel Uka ${ }^{1}$, Usunomena Usunobun ${ }^{2}$ \\ ${ }^{1}$ Biochemistry Department, Faculty of Basic Medical Sciences, University of Uyo, Akwa Ibom State, Nigeria \\ ${ }^{2}$ Basic Sciences Department (Biochemistry unit), Benson Idahosa University, Benin City, Edo State, Nigeria \\ *Corresponding author E-mail:efosaewere@yahoo.com
}

\begin{abstract}
This study was aimed at determining the phytochemical composition, antioxidant effect and acute toxicity of Irvingia gabonensis (O'Rorke) baill (IG) ethanolic leaf extract. Qualitative phytochemcal analysis was carried out on the ethanolic leaf extract using standard procedures. Different concentrations of the plant extract $(20 \mu \mathrm{g} / \mathrm{ml}-100 \mu \mathrm{g} / \mathrm{ml})$ were used to assess its effect on 1,1-diphenyl-2picrylhydrazyl (DPPH) free radical activity, It's reducing power and it total phenolic content. Lorke's method of acute toxicity was adopted for the acute toxicity study. Results obtained showed the presence of saponins, tannins, flavonoids, cardiac glycosides, steroids, and carbohydrates in the leaf extract. The ethanolic leaf extract of IG significantly $(\mathrm{P}<0.05)$ inhibited the activity of DPPH when compared with the vitamin $\mathrm{C}$ standard. IG leaf extract also showed a higher reducing power as compared with the Vitamin $\mathrm{C}$ standard. The total phenolic content of IG ethanolic leaf extract was however, significantly $(\mathrm{P}<0.05)$ lower than that of gallic acid, the standard used. Futhermore, the LD50 of the ethanolic leaf extract was found to be above $5000 \mathrm{mg} / \mathrm{kg}$ body weight. Irvingia gabonensis (O'Rorke) baill ethanolic leaf extract is a rich source of important phytochemicals and possesses a high antioxidant activity. Also, the administration of the ethanolic leaf extract in wistar rats is safe up to a dose of $5000 \mathrm{mg} / \mathrm{kg}$ body weight.
\end{abstract}

Keywords: 1,1-Diphenyl-2-Picrylhydrazyl (DPPH); Oxidative Stress; Antioxidants; Free Radicals; Irvingia gabonensis (O'Rorke) Baill.

\section{Introduction}

Free radicals like reactive oxygen and nitrogen species are an integral part of normal physiology (Wong et al. 2006). Reactive oxygen species (ROS) in the form of superoxide anion, hydrogen peroxide and hydroxyl radical are natural by-products of our body's metabolism (Nagalapur and Paramjyothi 2010). Excess amount of free radicals can attack biological molecules such as proteins, lipids, enzymes, DNA and RNA, culminating in cell or tissue injury associated with degenerative diseases (Nagalapur and Paramjgothi 2010). Epidemiological studies have shown that many phytonutrients of fruits and vegetables might protect the human body against damage by ROS. The consumption of natural antioxidant phytochemicals was reported to have potential health benefits (Di Carlo et al. 1999, Pulido et al. 2000, Sumino et al. 2002). Attentions have recently shifted to finding natural phytochemicals from plants with antioxidant activity. Flavonoids in particular and other polyphenols, have been reported to inhibit the propagation of free radical reactions to protect the human body from diseases (Kinsella et al. 1993, Terao and Piskula 1997). Studies are therefore ongoing with the aim of increasing the knowledge of antioxidant activities obtained from natural sources, such as plants.

Irvgingia gabonensis, (O'Rorke) Baill is a tropical forest tree mostly found in Southern and Eastern Nigeria, Sierra Leone and Equatorial Africa. It is a species from the family Irvingiaceae. The edible fruit pulp is sweet; it can be eaten, and it has a turpentine flavour (Udeala et al. 1980). This leaf is widely used in traditional medicine for the treatment of several illnesses (Lowe et al. 2000). The aqueous maceration of the leaves is used as antidote for some poisonous substances. In combination with palm oil, the leaves are also used to stop haemorrhage in pregnant women. In Senegal, the decoction of the stem bark is used in the treatment of gonorrhoea, hepatic and gastrointestinal disorders (Hubert et al. 2010).

A very important criterion that must be considered in the selection of herbal medicines for health use is the safety of such herbs. In addition to the potency of plant extracts, they must be safe for consumption. Therefore, it is not enough to screen plant extracts for their activities against diseases but also the toxicity limits of such plant extracts with traditionally acclaimed therapeutic properties must be investigated. This study was therefore conducted to determine the phytochemical composition, invitro antioxidant activity and acute toxicity of the ethanolic leaf extract of Irvgingia gabonensis, (O'Rorke) Baill owing to its wide traditional use.

\section{Methods}

\subsection{Collection, authentication and preparation of plant extract}

Fresh and matured leaves of Irvingia gabonensis (O'Rorke) Baill were collected from Obong Itam in Itu local government area, Akwa Ibom State, Nigeria. The leaves were authenticated by a plant taxonomist of the Department of Botany, University of Uyo, with the Herbarium number: SAM, UUH 3396 (Itu). They were washed and rinsed with distilled water to remove dust particles 
and air dried at room temperature for three days. The leaves were then pulverized with the aid of manual blender and stored in a closed, air-tight container, prior to extraction. About $300 \mathrm{~g}$ of the pulverized (powdered form) leaves was macerated in macerated tank using $70 \%$ ethanol and was sealed with a foil. The tank was shaken vigorously and regularly to ensure a good mixture. After 72 hours, the mixture was separated (filtered) using a glass funnel laid with a filter paper into a two litre beaker. The extract obtained was concentrated in a water bath set (Searl instruments, stae well, England) at $45^{\circ} \mathrm{C}$. The extract was further dried in a desiccator to eliminate any remaining water content in the extract at between 28 $-33^{\circ} \mathrm{C}$ and used for analyses.

\subsection{Phytochemical screening}

\subsubsection{Test for saponins}

a) Frothing test

This was carried out according to the method of Trease and Evans 1989. 0.1g of plant extract was introduced into a test tube containing $5 \mathrm{ml}$ of distilled water and shaken vigorously for one minute presence of frothing, which lasted for 30 minutes indicated the presence of saponins.

\subsubsection{Test for tannins}

The method of Trease and Evans 1989 was adopted. 0.1g of plan extract was striked with $5 \mathrm{ml}$ of distilled water, filtered and $5 \%$ ferric chloride reagent added to the filtrate. The formation of a blue-black, green or blue-green precipitate indicated the presence of tannins.

\subsubsection{Test for flavonoids}

The method of Sofowora 1993 was adopted. Few pieces of magnesium metal were added to $5 \mathrm{ml}$ of the extract followed by $2 \mathrm{ml}$ of concentrated $\mathrm{HCl}$. The formation of effervescences and orange colour indicated the presence of flavonoids.

\subsubsection{Test for cardiac glycosides}

The method of Trease and Evans 1989 was adopted. 0. 1g of the extract was dissolved in $2 \mathrm{ml}$ of chloroform; concentrated sulphuric acid was carefully added to form a lower layer. A reddishbrown colour at the interface indicated the presence of cardiac glycosides.

\subsubsection{Test for steroids}

The method of Wall et al. 1954 was adopted. 0.1g of plant extract was added to $3 \mathrm{ml}$ of chloroform and filtered, 5 drops of acetic anhydride was added to the filtrate followed by two drops of concentrated tetraoxosulphate (VI) acid. A bluish-green interface was observed suspected to be steroids.

\subsubsection{Test for anthraquinones}

The method of Trease and Evans 1989 was adopted. $0.1 \mathrm{~g}$ of plant extract was boiled with $5 \mathrm{ml}$ of $10 \%$ sulphuric acid and filtered. The filtrate was shaken with $2 \mathrm{ml}$ of benzene. The benzene layer was separated, and $10 \% \mathrm{NH}_{4} \mathrm{OH}$ was added and shaken. The appearance of a violet colour indicates the presence of anthraquinones.

\subsubsection{Test for carbohydrates (molisch test)}

The method of Trease and Evans 1989 was adopted. 0.1g of the extract was dissolved in $5 \mathrm{ml}$ of distilled water in a test tube. Few drops of molisch reagent were added and mixed thoroughly. $1 \mathrm{ml}$ of concentrated $\mathrm{H}_{2} \mathrm{SO}_{4}$ was then added slowly down the side of the inclined test tube so that the acid formed a layer beneath the tube. The appearance of a purple ring colour at the interface indicated the presence of carbohydrates.

\subsubsection{Test for Alkaloids}

The method of Trease and Evans 1989 was adopted. 0.1g of extract was weighed into a beaker in triplicate. $5 \mathrm{ml}$ of $1 \% \mathrm{HCl}$ was added and warmed in a water bath. To $1 \mathrm{ml}$ of the filtrate were treated with few drops of Dragendoff's reagent, Meyer's reagent, and Hager's reagent respectively. The appearance of orange, creamy, and yellow precipitates for Dragendoff's reagent, Meyer's reagent, and Hager's reagent respectively confirms positive result. Instead, green, light brown and no yellow precipates respectively appeared.

\subsection{Methods for antioxidant analysis}

\subsubsection{Determination of 1,1-diphenyl-2-picrylhydrazyl (DPPH) radical scavenging activity}

DPPH-free radical scavenging activity of Irvingia gabonensis (O'Rorke) Baill was measured using the method of Chang et al. 2001. The rate of reduction of a chemical reaction upon addition of 1,1-diphenyl-2-picrylhydrazyl (DPPH) is an indication of the radical nature of the reaction, with strong absorption band centered at $517 \mathrm{~nm}$. The DPPH has a violet colour in solution, which decolorizes to pale yellow when neutralized by the action of an antioxidant extract.

$0.1 \mathrm{mM}$ solution of DPPH in ethanol was prepared and $1 \mathrm{ml}$ of this solution was added to the extract solution in water at different concentrations $(20,40,60,80$ and $100 \mu \mathrm{g} / \mathrm{ml})$ respectively. The mixture was shaken vigorously and allowed to stand at room temperature for 30 minutes. Then the absorbance was measured at $517 \mathrm{~nm}$, using a UV-VIS spectrophotometer against ethanol blank. The capacity to scavenge DPPH radical was calculated as follows.

$\%$ inhibition $=\underline{\text { Acontrol-Asample } \mathrm{x} 100 \%}$ Acontrol

Where Acontrol is the absorbance of control and Asample is the absorbance of the IG extract sample and Vitamin C (standard used) respectively.

\subsubsection{Reducing power assay (RP)}

The reducing power of the ethanolic extract of Irvingia gabonensis (O'Rorke) Baill was determined by the method of Oyaizu 1986. This assay method is based on the principle of increase in the absorbance of the reaction mixtures. The higher the absorbance value, the higher the antioxidant activity. In this method, antioxidant compounds form a coloured complex with potassium ferricyanide, trichloro acetic acid and ferric chloride, which is measured at $700 \mathrm{~nm}$. Increase in absorbance of the reaction mixture indicates the reducing power of the samples.

Different concentrations of the extract and vitamin C standard (20, $40,60,80$ and $100 \mu \mathrm{g} / \mathrm{ml}$ ) in $1 \mathrm{ml}$ of distilled water were mixed with $2.5 \mathrm{ml}$ of $0.2 \mathrm{M}$ phosphate buffer and $2.5 \mathrm{ml}$ of $1 \%$ potassium ferricyanide. The mixture was incubated at $50^{\circ} \mathrm{C}$ for 20 minutes. $2.5 \mathrm{ml}$ of $10 \%$ trichloroacetic acid was added to the mixture which was then centrifuged for 10 minutes at $3000 \mathrm{rpm}$. The supernatant was mixed with $2.5 \mathrm{ml}$ of distilled water and $0.5 \mathrm{ml}$ of $0.1 \% \mathrm{FeCl}_{3}$ and the absorbance was measured at 700nm using a UV-VIS spectrophotometer.

\subsubsection{Determination of total phenolic content}

This was determined spectrophotometrically with Folin-Ciocalteu reagent by modified method of Wolfe et al. (2003). 10.5ml) of extract was mixed with $2.5 \mathrm{ml}$ of $10 \%$ Folin-Ciocaltau reagent and $2 \mathrm{ml}$ of $\mathrm{Na}_{2} \mathrm{CO}_{3}$. The resulting mixture was vortexed for 15 second and incubated at $40^{\circ} \mathrm{C}$ for 30 minutes for colour development. The absorbance of the samples was measured at $765 \mathrm{~nm}$. Total phenolic content was expressed as $\mathrm{mg} / \mathrm{g}$ gallic acid equivalent from the calibration curve using the equation $\mathrm{Y}=0.006 \mathrm{x}+0.039$ where, $\mathrm{x}$ 
is the absorbance. Experiment was conducted in triplicate, and the results were expressed as mean \pm Standard Deviation.

\subsection{Acute toxicity study}

Lorke's method (1983) was adopted in the determination of the $\mathrm{LD}_{50}$ of the leaf extract. The study was divided into two phases using a total of fifteen (15) male wistar albino rats of weights between $75-145 \mathrm{~g}$. They were allowed to acclimatize for about two weeks and fasted overnight just before the commencement of the experiment for body weight determination. In phase one, nine (9) rats were randomised into three groups of three rats each and were administered IG leaf extract at 10,100 , and $1000 \mathrm{mg} / \mathrm{kg}$ body weight (b.w) respectively in order to possibly establish the range of doses that would produce any toxic effect. Additionally, a fourth group of three rats was set up as control group and animals in the group were not given the extract. In the second phase, 1600, 2900 and $5000 \mathrm{mg} / \mathrm{kg} \mathrm{b.w}$. of the extract were administered to three rats of one rat per dose to further determine the correct $\mathrm{LD}_{50}$ value. Extract administration was done by oral intubation. All animals were observed frequently on the day of treatment and surviving animals were monitored daily for 14 days for signs of acute toxicity. At the end of the 14days, all surviving rats were sacrificed, and liver organs extracted and examined macroscopically for pathological changes compared with the control group. Percentage body weight changes and relative liver weights were also recorded.

\subsection{Data analysis}

The experimental results were expressed as mean \pm standard deviation (SD) of three replicates. Results were analysed using oneway analysis of variance (ANOVA) where applicable with the aid of SPSS Statistical software. P values at $<0.05$ were considered statistically significant.

\section{Results}

\subsection{Results of the phytochemical screening of ethanolic leaf extract of Irvingia gabonensis (O'Rorke) baill}

Preliminary phytochemical screening of Irvingia gabonensis (O'Rorke) baill ethanolic leaf extract revealed the presence of saponins, tannins, flavonoids, steroids, cardiac glycosides and carbohydrates as seen in table 1.0

Table 1: Phytochemical Constituents of Irvingia Gabonensis (O'Rorke) Baill Ethanolic Leaf Extract.

\begin{tabular}{ll}
\hline Phytochemical Constituent & Inference \\
\hline Saponins & +++ \\
Tannins & + \\
Flavonoids & +++ \\
Steroids & +++ \\
Cardiac Glycosides & ++ \\
Carbohydrates & +++ \\
Anthraquinones & - \\
Alkaloids & - \\
\hline Keys: & \\
+ & Present in a trace concentration \\
++ & Present in a medium concentration \\
+++ & Present in a high concentration \\
- & Absent or in negligible amount
\end{tabular}

3.2. Effect of Irvingia gabonensis (O'Rorke) baill (IG) ethanolic leaf extract on 1,1-diphenyl-2-picryl-hydrazyl (DPPH) radical activity compared with vitamin $\mathrm{C}$.

Table 2 shows the results obtained for the DPPH scavenging activities of both Irvingia gabonensis (O'Rorke) baill (IG) ethanolic leaf extract and vitamin $\mathrm{C}$ (ascorbic acid) which was the standard used. At the different respective concentrations of $20,40,60,80$ and $100 \mu \mathrm{g} / \mathrm{ml}$ for extract and ascorbic acid, the percentage inhibitions of the extract were $40 \%, 62 \%, 74 \%, 88 \%$ and $95 \%$. Those of Vitamin $\mathrm{C}$ (ascorbic acid) at the different concentrations were $28 \%, 45 \%, 63 \%, 71 \%$ and $90 \%$ respectively.

Table 2: Effect of Irvingia Gabonensis (O’Rorke) Baill (IG) Ethanolic Leaf Extract on 1,1-Diphenyl-2-Picryl-Hydrazyl (DPPH) Radical Activity - Compared with Vitamin C

\begin{tabular}{lllll}
\hline $\begin{array}{l}\text { Concentration } \\
(\mu \mathrm{g} / \mathrm{ml})\end{array}$ & $\begin{array}{l}\text { IG Absorb- } \\
\text { ance } \\
(\text { Mean } \pm \text { SD) }\end{array}$ & $\begin{array}{l}\text { Vit.C Ab- } \\
\text { sorbance } \\
(\text { Mean } \pm \text { SD })\end{array}$ & $\begin{array}{l}\text { IG \% } \\
\text { Inhibition } \\
\text { Of DPPH }\end{array}$ & $\begin{array}{l}\text { Vit.C \% } \\
\text { Inhibition } \\
\text { Of DPPH }\end{array}$ \\
\hline 20 & $1.17 \pm 0.00$ & $1.93 \pm 0.00$ & $40 \%$ & $28 \%$ \\
40 & $1.20 \pm 0.00$ & $1.47 \pm 0.00$ & $62 \%$ & $45 \%$ \\
60 & $0.51 \pm 0.00$ & $1.69 \pm 0.00$ & $74 \%$ & $63 \%$ \\
80 & $0.26 \pm 0.00$ & $1.80 \pm 0.00$ & $88 \%$ & $71 \%$ \\
100 & $1.11 \pm 0.00$ & $2.42 \pm 0.00$ & $95 \%$ & $90 \%$ \\
\hline
\end{tabular}

Data presented as (Mean \pm SD), $n=3$

\subsection{Reducing power (RP) of Irvingia gabonensis (O'Rorke) baill (IG) compared with vitamin C (ascorbic acid) standard}

Table 3 shows the results of the reducing power of both Irvingia gabonensis (O'Rorke) baill (IG) ethanolic leaf extract and vitamin $\mathrm{C}$ (ascorbic acid) which was the standard used. At the different respective concentrations of $20,40,60,80$ and $100 \mu \mathrm{g} / \mathrm{ml}$ for extract and ascorbic acid, the reducing power of the extract expressed as mean \pm standard deviation (SD) of absorbance values were $0.34 \pm 0.00,0.37 \pm 0.00,0.40 \pm 0.00,0.43 \pm 0.00$ and $0.45 \pm$ 0.00 respectively while those of ascorbic acid were $0.26 \pm 0.00$, $0.28 \pm 0.00,0.29 \pm 0.00,0.33 \pm 0.00$, and $0.35 \pm 0.00$.

Table 3: Reducing Power (RP) of Irvingia Gabonensis (O'Rorke) Baill (IG) Compared with Ascorbic Acid Standard

\begin{tabular}{lll}
\hline $\begin{array}{l}\text { Concentration } \\
(\mu \mathrm{g} / \mathrm{ml})\end{array}$ & $\begin{array}{l}\text { IG Extract Absorb- } \\
\text { ancevalues }\end{array}$ & $\begin{array}{l}\text { Vitamin C Absorbance } \\
\text { values }\end{array}$ \\
\hline 20 & $0.34 \pm 0.00$ & $0.26 \pm 0.00$ \\
40 & $0.37 \pm 0.00$ & $0.28 \pm 0.00$ \\
60 & $0.40 \pm 0.00$ & $0.29 \pm 0.00$ \\
80 & $0.43 \pm 0.00$ & $0.33 \pm 0.00$ \\
100 & $0.45 \pm 0.00$ & $0.35 \pm 0.00$ \\
\hline
\end{tabular}

Data presented as (Mean $\pm \mathrm{SD}), \mathrm{n}=3$

\subsection{Total phenolic content of Irvingia gabonensis} (O'Rorke) baill (IG) compared with Gallic acid

Table 4 shows the results obtained for the total phenolic content of Irvingia gabonensis (O'Rorke) Baill (IG) and gallic acid (standard used). At the different respective concentrations of $20,40,60,80$ and $100 \mu \mathrm{g} / \mathrm{ml}$ for extract and gallic acid, the total phenolic content of the extract expressed as mean \pm standard deviation (SD) $\mathrm{mg} / \mathrm{g}$ gallic acid equivalence were $0.11 \pm 0.01,0.14 \pm 0.02,0.20 \pm 0.01$, $0.22 \pm 0.01$ and $0.24 \pm 0.01$ while those of gallic acid were $0.18 \pm$ $0.00,0.37 \pm 0.00,0.54 \pm 0.01,0.73 \pm 0.01$ and $0.92 \pm 0.01$.

Table 4: Estimation of Total Phenolic Content of Irvingia Gabonensis (O’Rorke) Baill (IG) Compared with Gallic Acid

\begin{tabular}{lll}
\hline $\begin{array}{l}\text { Concentration } \\
(\mu \mathrm{g} / \mathrm{ml})\end{array}$ & IG Extract (mg/g GAE) & Gallic Acid (mg/g GAE) \\
\hline 20 & $0.11 \pm 0.01$ & $0.18 \pm 0.00^{*}$ \\
40 & $0.14 \pm 0.02$ & $0.37 \pm 0.00^{*}$ \\
60 & $0.20 \pm 0.01$ & $0.54 \pm 0.01^{*}$ \\
80 & $0.22 \pm 0.01$ & $0.73 \pm 0.01^{*}$ \\
100 & $0.24 \pm 0.01$ & $0.92 \pm 0.01^{*}$ \\
\hline
\end{tabular}

Data presented as (Mean $\pm \mathrm{SD}), \mathrm{n}=3$

$\mathrm{GAE}=$ Gallic acid equivalence

* indicates that the value is significantly different at $\mathrm{P}<0.05$ when compared with the other at same concentration 


\subsection{Acute lethal effect of ethanolic leaf extract of Irvin- gia gabonensis (O'Rorke) baill on male wistar albino rats}

No death was recorded for any of the experimental rats even at the highest dose of $5000 \mathrm{mg} / \mathrm{kgbw}$ after 24 hours of treatment and after the 14 days period of observation and no signs of toxicity was observed. Also, no macroscopic pathological changes were observed in all the liver organs extracted. There was no significant difference $(p>0.05)$ in the percentage change in weight and relative liver weights among all experimental groups (where applicable). The oral $\mathrm{LD}_{50}$ was therefore found to be higher than $5000 \mathrm{mg} / \mathrm{kgbw}$.

Table 5: Mortality Rate of Experimental Rats in Phases I and II of Acute Toxicity Study

\begin{tabular}{|c|c|c|}
\hline $\begin{array}{l}\text { Experiment / } \\
\text { Group }\end{array}$ & Treatment & $\begin{array}{l}\text { No. of deaths after } 24 \\
\text { hours }\end{array}$ \\
\hline \multicolumn{3}{|l|}{ Phase I } \\
\hline 1 & $10 \mathrm{mg} / \mathrm{kg}$ bw IG extract & $0 / 3$ \\
\hline 2 & $\begin{array}{l}100 \mathrm{mg} / \mathrm{kg} \text { bw IG ex- } \\
\text { tract }\end{array}$ & $0 / 3$ \\
\hline 3 & $\begin{array}{l}1000 \mathrm{mg} / \mathrm{kg} \text { bw IG } \\
\text { extract }\end{array}$ & $0 / 3$ \\
\hline $\begin{array}{l}\text { Control } \\
\text { Phase II }\end{array}$ & 0 & $0 / 3$ \\
\hline 1 & $\begin{array}{l}1600 \mathrm{mg} / \mathrm{kg} \text { bw IG } \\
\text { extract }\end{array}$ & $0 / 1$ \\
\hline 2 & $\begin{array}{l}2900 \mathrm{mg} / \mathrm{kg} \text { bw IG } \\
\text { extract }\end{array}$ & $0 / 1$ \\
\hline 3 & $\begin{array}{l}5000 \mathrm{mg} / \mathrm{kg} \text { bw IG } \\
\text { extract }\end{array}$ & $0 / 1$ \\
\hline
\end{tabular}

Table 6: Effect of IG Ethanolic Leaf Extract on Body and Liver Weights, of Experimental Rats.

\begin{tabular}{|c|c|c|c|}
\hline $\begin{array}{l}\text { Experiment / } \\
\text { Group }\end{array}$ & Treatment & $\begin{array}{l}\text { Percentage Change } \\
\text { in Body Weight }(\%)\end{array}$ & $\begin{array}{l}\text { Relative } \\
\text { Liver Weight } \\
(\%)\end{array}$ \\
\hline \multicolumn{4}{|l|}{ Phase I } \\
\hline 1. & $\begin{array}{l}10 \mathrm{mg} / \mathrm{kg} \text { bw IG } \\
\text { extract }\end{array}$ & $21.81 \pm 3.01$ & $3.70 \pm 0.28$ \\
\hline 2. & $\begin{array}{l}100 \mathrm{mg} / \mathrm{kg} \text { bw } \\
\text { IG extract }\end{array}$ & $18.05 \pm 1.86$ & $3.87 \pm 0.26$ \\
\hline 3. & $\begin{array}{l}1000 \mathrm{mg} / \mathrm{kg} \text { bw } \\
\text { IG extract }\end{array}$ & $16.25 \pm 6.88$ & $3.99 \pm 0.42$ \\
\hline Control & 0 & $19.24 \pm 1.41$ & $3.82 \pm 1.09$ \\
\hline \multicolumn{4}{|l|}{ Phase II } \\
\hline 1. & $\begin{array}{l}1600 \mathrm{mg} / \mathrm{kg} \text { bw } \\
\text { IG extract }\end{array}$ & 3.59 & 3.57 \\
\hline 2. & $\begin{array}{l}2900 \mathrm{mg} / \mathrm{kg} \text { bw } \\
\text { IG extract }\end{array}$ & 5.66 & 4.15 \\
\hline 3. & $\begin{array}{l}5000 \mathrm{mg} / \mathrm{kg} \text { bw } \\
\text { IG extract }\end{array}$ & 2.43 & 3.28 \\
\hline
\end{tabular}

$\mathrm{Mg} / \mathrm{kgbw}=$ milligram/kilogram body weight, $\mathrm{IG}=$ Irvingia gabonensis

\section{Discussion}

Different plant parts have been used for ages for several purposes ranging from food to medicine and herbal medicine practitioners and most locals use different plant parts for therapeutic purposes (Tanaka et al. 2002). This has led to massive scientific research into the therapeutic utilization of different plants. It is now generally known that most therapeutic effects of medicinal plants owe to their phytochemical constituents and as such in recent years, secondary plant metabolites also referred to as phytochemicals have been investigated extensively as sources of medicinal agents (Krishnaraju et al. 2005). This present study was therefore carried out to investigate the phytochemical composition of Irvingia gabonensis (O'Rorke) baill ethanol leaf extract and it's in vitro antioxidant activity as the leaves have been used by locals for therapeutic purposes (Surville 1955, Hubert et al. 2010) and oxidative stress, which is counteracted by antioxidants has been implicated in the etiology of different diseases (Heo et al. 2005, Guo et al. 2011).

In the present study, qualitative phytochemical screening of the ethanol leaf extracts of Irvingia gabonensis (O'Rorke) baill revealed the presence of saponins, tannins, flavonoids, steroids, cardiac glycosides and carbohydrates. Tannins, phenols and polyphenols including flavonoids are known to combat the harmful effects of free radicals in the human body (Narasimhan et al. 2006). Tannins have been reported to possess antioxidant, antimicrobial and anti-inflammatory properties (Okwu and Okwu 2004). The anti-oxidants, anti-carcinogenic, anti-microbial and antitumor properties of flavonoids have also been reported (Manikandan et al. 2006). Also, epidemiological studies have shown that heart diseases are inversely related to flavonoid intake (Le Marchand 2002). Saponins have been reported to help in the control of blood cholesterol levels, bone health, building of the immune system and cancer (Matsuura 2001). Cardiac glycosides have been reported to be used in the treatment of congestive heart failure and arrhythmia (Ehle et al. 2011) and also to possess anticancer activities (Newman et al., 2008, Perne et al. 2009, Ye et al. 2011, Tailler et al. 2012, Menger et al. 2012). Steroids are of importance and of great interest owing to their relationship with sex hormones (Okwu 2001).

Free radicals have been implicated in the development of several diseases and are easily produced via normal metabolic pathways in the body. Conversely, antioxidants have the ability of combating free radicals thereby preventing diseases. Natural antioxidants of plant origin have been linked with the reduction of chronic diseases as they have the capacity of terminating the propagation of free radicals in the body (Covacci et al. 2001). This is widely utilized as a parameter in characterizing medicinal potentials of plants.

1,1-diphenyl-2-picrylhydrazyl (DPPH) is characterized as a stable free radical due to the delocalization of the spare electron over the entire molecule, preventing the molecule from dimerizing, as would be the case with most other free radicals. The delocalization of electron also gives rise to the deep violet color, characterized by an absorption band in ethanol solution centered at about $517 \mathrm{~nm}$. When a solution of DPPH is mixed with that of a substrate (antioxidant) that can donate a hydrogen atom, it this gives rise to the reduced form with the loss of this violet color (Alam et al. 2013). In the present study, Irvingia gabonensis (O'Rorke) baill ethanolic leaf extract scavenged DPPH radical in a concentration dependent manner and the percentage inhibition of the extract was significantly $(\mathrm{P}<0.05)$ higher than that of the ascorbic acid standard used at the respective concentrations. The $\mathrm{IC}_{50}$ (the concentration of an inhibitor at which $50 \%$ inhibition of the response is seen) of the Irvingia gabonensis (O'Rorke) baill ethanolic leaf extract was $27.9 \mu \mathrm{g} / \mathrm{ml}$ and that of the ascorbic acid standard was $47.5 \mu \mathrm{g} / \mathrm{ml}$ respectively. This reveals the very high antioxidant activity of the extract which may be due to the presence of antioxidant phytochemicals present in it as seen from the results obtained from the phytochemical screening of the Irvingia gabonensis (O'Rorke) baill ethanolic leaf extract. The mechanism by which the Irvingia gabonensis (O'Rorke) baill ethanolic leaf extract scavenged DPPH radical maybe via the donation of hydrogen atom to it by hydrogen-donating antioxidant phytochemicals present in the leaf extract thereby producing the non-radical form (Alam et al. 2013). Reducing power of a particular compound is a function of its antioxidant activity and serves as a very important reflection of the antioxidant activity (Oktay et al. 2003). Compounds with reducing power are donors of electrons and can reduce the oxidized intermediates of lipid peroxidation processes and so can act as primary and secondary antioxidants (Yen and Chen 1995). In the present study, the reducing power of Irvingia gabonensis (O'Rorke) baill ethanolic leaf extract increased in a concentration-dependent man- 
ner and was far higher than that of the ascorbic acid standard used. This further reflects the very high antioxidant activity of the leaf extract and may justify the use of Irvingia gabonensis (O'Rorke) baill leaf as an antidote by some locals.

The results obtained for the total phenolic content of the leaf extract also increased in a concentration dependent manner but was however significantly $(\mathrm{P}<0.05)$ lower than that of the gallic acid standard used which is a pure phenolic acid. As earlier stated, plant polyphenols have been reported to possess very high antioxidant effects (Rice-Evans et al. 1996, Re et al. 1999, Villano et al. 2007).

Acute toxicity studies are very vital in understanding the toxicity profiles of plant extracts (Ozbek et al. 2004). In the present study, the result of the acute oral toxicity of the ethanolic leaf extract of Irvingia gabonensis (O'Rorke) baill in Wistar albino rats revealed the $\mathrm{LD}_{50}$ to be beyond $5000 \mathrm{mg} / \mathrm{kg}$ body weight as the experimental rats tolerated the extract with no symptom of acute toxicity (no mortality, skin changes, aggressiveness, diarrhoea, restiveness, seizures, dizziness, weakness, or withdrawal from either food or water) even at higher doses of the extract. Futhermore, analysis of organ weight in toxicology studies is an important endpoint for identification of potentially harmful effects of chemicals (Steven et al. 2004). Organ weight can be the most sensitive indicator of the effect of an experimental compound, as significant differences in organ weight between treated and untreated (control) animals may occur in the absence of any morphological changes (Steven et al. 2004). The fact that no macroscopic pathological changes were observed in all the liver organs extracted and no significant difference ( $p>0.05)$ in the percentage change in weight and relative liver weights among all experimental groups was recorded suggests the non-toxicity of the extract.

It is known that the lower the $\mathrm{LD}_{50}$, the more toxic the extract is and the higher the $\mathrm{LD}_{50}$ value, the lower the toxicity of the tested extract (Gadanya et al. 2011). Thus, the ethanolic leaf extract of Irvingia gabonensis (O'Rorke) baill is considered safe as extracts or chemicals with $\mathrm{LD}_{50}$ beyond $5000 \mathrm{mg} / \mathrm{kg}$ body weight are considered safe (Lorke 1983).

From the results obtained, it can be concluded that ethanolic leaf extract of Irvingia gabonensis (O'Rorke) baill is an important source of vital phytochemicals and possesses a high antioxidant activity. Furthermore, the extract is considered non-toxic up to an oral dose of $5000 \mathrm{mg} / \mathrm{kg}$ body weight in Wistar albino rats.

\section{Acknowledgements}

Special appreciation goes to the Departments of Pharmaceutical Chemistry and Biochemistry, University of Uyo, Akwa Ibom State, Nigeria for allowing the use of the respective laboratories and the animal house for this study.

\section{References}

[1] AlamMN, Bristi NJ and Rafiquzzaman M. (2013) Review on in vivo and in vitro Methods of Evaluation of Antioxidant Activity. Saudi Pharmaceutical Journal. 21: 143-152. http://dx.doi.org/10.1016/j.jsps.2012.05.002.

[2] Chang ST, Wu, JH, Wang SH., KangP.L, Yang NS and Shyur L.F (2001) Antioxidant Activity of Extracts from Acacia confusa Bark and Heartwood. Journal of Agricultural and Food Chemistry. 49: 3420-3424. Pubs.acs.org. http://dx.doi.org/10.1021/jf0100907.

[3] Covacci V, Torsello A, Palozza P, Sgambato A, Romano G, Boninsegna A, Cittadini A. and Wolf FI. (2001) DNA oxidative damage during differentiation of HL-60 human promyelocytic leukemia cells. Chemical Research in Toxicology.14:1492-7. Pubs.acs.org/doi/abs/10.../tx010021m

[4] Dicarlo G, Maxolo N, Izzo A. and Capasso F. C. (1999) Flavonoids: Old and New Aspects of a Class of Therapeutic Drugs. Life Sciences. 65: 337-353. http://dx.doi.org/10.1016/S0024 3205(99)00120-4.

[5] Ehle M, Patel C. and Giugliano RP. (2011) Digoxin: Clinical Highlights: A Review of Digoxin and its Use in Contemporary Medi- cine. Critical Pathways in Cardiology. 10: 93-8. Doi: 10.1097/HPC.0b013e31221e7dd.

[6] Gadanya AM, Sule MS. and Atiku MK. (2011) Acute Toxicity Study of "Gadagi" Tea on Rats. Bayero Journal of Pure and Applied Sciences. $\quad 4(2): \quad 147 \quad-\quad 149$. http://dx.doi.org/10.4314/bajopas.v4i2.29.

[7] Guo T, Wei L, Sun J, Hou C. and Fan L. (2011) Antioxidant Activities of Extract and Fractions from Tuber indicumCooke \&Massee. Food Chemistry.127: http://dx.doi.org/10.1016/j.foodchem.2011.02.030.

[8] Heo SJ, Park EJ, Lee KW and Jeon Y.J. (2005) Antioxidant Activities of Enzymatic Extracts from Brown Seaweeds. Bioresource. Technology. 96 : http://dx.doi.org/10.4490/ALGAE.2003.18.1.071.

[9] Hubert DJ, Wabo FG, Ngameni B, Ngheguin TF, Tchoukoua A, Ambassa P, Abia W, Tchana AN, Giardina S, Buonocore D, Vita FP, Vidari G, Marzatico F, Ngadjui BT. and Moundipa PF. (2010) "In vitrohepatoprotective and antioxidant activities of the crude extract and isolated compounds from Irvingia gabonensis. Asian Journal of Traditional Medicine. 5(3): 79-88.

[10] Kinsella JE, Frankel E, German BJ and Kannder J. (1993) Possible Mechanism for the Protective Role of Antioxidants in Wine and Plant Foods. Food Technology. 47: 85-89.

[11] Krishnaraju AV, Rao TVN, Sundararaju D. Vanisree M, Tsay H and Subbaraju GV. (2005) Assessment of Bioactivity of Indian Medicinal Plants using Brine Shrimp (Artemiasalina) lethality assay. International Journal of Applied Science and Engineering 2 125-134.

[12] Le Marchand L. (2002) Cancer Preventive Effects of flavonoids-A review. Biomedicine and Pharmacotherapy. 56:296-301. http://dx.doi.org/10.1016/S0753-3322(02)00186-5.

[13] Lorke D. (1983) A new approach to practical acute toxicity testing. Archives of Toxicology. 53:275-287. http://dx.doi.org/10.1007/BF01234480.

[14] Lowe AJ, Gillies ACM, Wilson J. and Dawson IK. (2000) Conservation genetics of Bush Mango from Central/West Africa: Implications for RAPD analysis. Molecular Ecology. 9(7): 831 - 841 http://dx.doi.org/10.1046/j.1365-294x.2000.00936.x.

[15] Manikandan L, Senthilkumar GP, Rajesh LT, and Suresh R. (2006) Cancer Chemopreventive Agents from Medicinal Plants. In: Trivedi, P.C. Medicinal Plants: Ethnobotanical approach. Agrobios, India.

[16] Matsuura M. (2001) Saponins in Garlic as Modifiers of the Risk of Cardiovascular Disease. Journal of Nutrition 131:1000-1005.

[17] Menger L, Vacchelli E, Adjemian S, Martins I, Ma Y, Shen S, Yamazaki T, Sukkurwala AQ, Michaud M, Mignot G, Schlemmer F, Sulpice E, Locher C, Gidol X, Ghiringhelli F, Modjtahedi N, Galluzzi L, Andre F, Zitvogel L, Kepp O. and Kroemer G. (2012) Cardiac Glycosides Exert Anticancer Effects by Inducing Immunogenic Cell Death. Science Translational Medicine. 4: 143ra99. http://dx.doi.org/10.1126/scitranslmed.3003807.

[18] NagalapurSK and Paramjyothi S. (2010) In-vitro Antioxidant Activity of LaunaneapinnatifidacassLeaves. The Bioscan 5(1): 105108.

[19] Narasimhan S, Shobana R. and Sathya TN. (2006) Antioxidants Natural Rejuvenators that Heal, Detoxify and Provide Nourishment. In: Rakesh, K.S., Rajesh, A. (eds). Herbal Drugs: A Twenty First Century Prospective. New Delhi. J.P Brothers Medical Publishers. 548-57.

[20] Newman RA, Yang P, Pawlus AD and Block KI. (2008) Cardiac Glycosides as Novel Cancer Therapeutic Agents. Molecular Interventions. 8: 36-49. http://dx.doi.org/10.1124/mi.8.1.8.

[21] Oktay M, Gulcin I. and Kufrevioglu OI. (2003) Determination of in vitro Antioxidant Activity of Fennel (Foeniculumvulgare) Seed Extracts.Lebanon.Wissen Technology. 36: 263-271. http://dx.doi.org/10.1016/S0023-6438(02)00226-8.

[22] Okwu DE. (2001) Evaluation of the Chemical Composition of Indigenous Spices and Flavouring Agents. Global Journal of Pure and Applied Sciences. 7(3): 455- 459 http://dx.doi.org/10.4314/gjpas.v7i3.16293.

[23] Okwu DE and Okwu ME. (2004) Chemical Composition of Spondiasmombin Linn. Plant Parts. Journal of Sustainable Agriculture and the Environment. 6(2):140 - 147.

[24] Oyaizu M. (1986) Studies on Products of Browning Reaction: Antioxidative Activity of Product of Browning Reaction Prepared from Glucosamine. Japanese Journal of Nutrition. 44: 307-315. http://dx.doi.org/10.5264/eiyogakuzashi.44.307.

[25] Ozbek H, Ozturk M, Ozturk A, Ceylan E. and Yener Z. (2004) Determination of Lethal Doses of Volatile and Fixed Oils of Several Plants. Eastern Journal of Medicine. 9 (1): 4 - 6. 
[26] Perne A, Muellner MK, Steinrueck M, Craig-Mueller N, Mayerhofer J, Schwarzinger I, Sloane, M, Uras IZ, Hoermann G, Nijman, SMB, and Mayerhofer M. (2009) Cardiac Glycosides Induce Cell Death in Human Cells by Inhibiting General Protein Synthesis. PLoS One. 4: $\quad$ e8292. http://dx.doi.org/10.1371/journal.pone.0008292.

[27] Pulido R, Bravo L. and Savana-Calixto F. (2000) Antioxidant Activity of Dietary Polyphenols as Determined by a Modified Ferric Reducing Antioxidant Power Assay. Journal of Agricultural and Food Chemistry. $48 \quad$ (8): $3396 \quad-\quad 3402$. http://dx.doi.org/10.1021/jf9913458.

[28] Re R, Pellegrini N, Proteggente A, Pannala A, Yang M. and RiceEvans C. (1999) Antioxidant Activity Applying an Improved ABTS Radical CationDecolorization Assay. Free Radical Biology and Medicine.26: 1231-1237. $\quad$ http://dx.doi.org/10.1016/S08915849(98)00315-3.

[29] Rice-Evans CA, Miller NJ and Paganga G. (1996) StructureAntioxidant Activity Relationships of Flavonoids and Phenolic Acids. Free Radical Biology and Medicine.20: 933-956. http://dx.doi.org/10.1016/0891-5849(95)02227-9.

[30] Sofowora A. (1993) Medicinal plants and Traditional Medicine in Africa. 2nd Ed. Sunshine House, Ibadan, Nigeria. Spectrum Books Ltd. Pp. 134-156.

[31] Steven A, Bailey Robert H, Zidell, and Richard WP. (2004) Relationships between Organ Weight and Body/Brain Weight in the Rat: What Is the Best Analytical Endpoint? Toxicologic Pathology. 32:448-466. http://dx.doi.org/10.1080/01926230490465874.

[32] Sumino, Sekine T., Ruangrungsi N, Igarashi K, and Ikegami F. (2002) Ardsiphenols and other Antioxidant Principles from the Fruits of Ardisiacolorata. Chemical and Pharmaceutical Bulletin 50 (11): 1484 - 1487.http://dx.doi.org/10.1248/cpb.50.1484.

[33] Surville N. (1955) Notes surquelquesplantesmedicamenteuses du Sud-Cameroun. ORSTOM. Yaounde. P. 10.

[34] Tailler M, Senovilla L, Lainey E, Thépot S, Métivier D, Sébert M, Baud V, Billot K, Fenaux P, Galluzzi L, Boehrer S, Kroemer G and Kepp O. (2012) Antineoplastic Activity of Ouabain and Pyrithione Zinc in Acute Myeloid Leukemia. Oncogene. 31: 3536-46. http://dx.doi.org/10.1038/onc.2011.521.

[35] Tanaka H, Sato M. and Fujiwara S. (2002) Antibacterial Activity of Isoflavonoids Isolated from Erythrinavariegata Against Methicillin-resistant Staphylococcus aureus. Letters in Applied Microbiology 35: $494 \quad-498$. http://dx.doi.org/10.1046/j.1472765X.2002.01222.x.

[36] Terao J. and Piskula M. (1997) Flavonoids as Inhibitors of Lipid peroxidation in Membranes. Life Science. 87: 263 - 269.

[37] Trease GE and Evans WC. (1989) Pharmacognosy, $13^{\text {th }}$ Ed. ELBS/BailliereTindall, London. Pp 345-773.

[38] Udeala O, Onyechi J. and Agu S. (1980) Sourcing Pharmaceutical Raw Materials from Indigenous Medicinal plants. Journal of Pharmacy and Pharmacology. 32:36.

[39] Villaño D, Fernández-Pachón MS, Moyá ML, Troncoso AM and García-Parrilla M.C. (2007) Radical Scavenging Ability of Polyphenolic Compounds Towards DPPH Free Radical. Talanta71: 230-235. http://dx.doi.org/10.1016/j.talanta.2006.03.050.

[40] Wall ME, Krider MM, Krewson CF, Eddy CR, Willaman JJ, Corell D.S. and Gentry H.S. (1954) Steroidal Sapogenins VII: Survey of Plants for Steroidal Sapogenins and other Constituents. Journal of American Pharmacists Association. 63: 1-7. http://dx.doi.org/10.1002/jps.3030430102.

[41] Wolfe K. and Liv RH. (2003) Antioxidant Activity of Apple Peels. Journal of Agriculture and Food Chemistry. 51: 609- 614. http://dx.doi.org/10.1021/jf020782a.

[42] Wong SP, Leong LP and Jen HWK. (2006) Antioxidant Activities of Aqueous Extracts of Selected Plants. Food Chemistry. 99(4): 775-783.http://dx.doi.org/10.1016/j.foodchem.2005.07.058.

[43] Ye J, Chen S. and Maniatis T. (2011) Cardiac Glycosides are Potent Inhibitors of Interferon- $\beta$ gene Expression. Nature Chemical Biology. 7: 25-33. http://dx.doi.org/10.1038/nchembio.476.

[44] Yen GC and Chen HY. (1995) Antioxidant Activity of Various Tea Extracts in Relation to their Antimutagenicity. Journal of Agricultural and Food Chemistry. 43: 27-32. http://dx.doi.org/10.1021/jf00049a007. 